\title{
Meteorite claims revitalize plans for further Mars missions
}

\begin{abstract}
Washington. The US space agency began looking this week into how it might revamp - and possibly accelerate - its Mars exploration programme, in the light of new evidence of past life on the planet and a presidential call for a summit meeting to chart a course for the nation's future in space.
\end{abstract}

A study team representing several National Aeronautics and Space Administration (NASA) centres, universities and the Lockheed Martin Corporation, which is building the first Mars Surveyor spacecraft due to be launched in November, planned to meet this week in

Washington DC to assess technical and financial options for changing the current line-up of Mars missions. These plans call for launching Mars Surveyors at each of five opportunities - 1996, 1998, 2001, 2003 and 2005 - at a total cost of approximately $\$ 1$ billion.

The dramatic claim last week by a team from NASA's Johnson Space Center in Houston, Texas, that they had found fossils in a Martian meteorite (see pages 575-576) set off a wave of excitement around the world, as well as in Congress and the White House. While the agency's administrator, Daniel Goldin, was careful not to imply that NASA would automatically boost its budget for Mars exploration, he said "we may want to consider some very bold missions where we bore down real deep, and we bring back samples". A sample-return mission is not currently part of the Surveyor plan, and many scientists are sceptical that the agency can afford one within its current science budget (see Nature 382, 481; 1996).

Jurgen Rahe, who heads NASA's planetary exploration effort, said the new study is

\section{IMAGE UNAVAILABLE FOR COPYRIGHT REASONS}

NASA funding. Mikulski, as well as Republicans on the House of Representatives Science Committee, is concerned that sixyear budget projections released by the White House early this year do not include enough money for NASA missions already on the books. Gore's staff said last week that they had just begun working on plans for the bipartisan summit, and are not yet sure whether it will involve \$n the scientific community as well as politicians. It is expected to take place in early December.

An accelerated programme to study Mars - either directly or through

meant as contingency planning only, in case the agency should be asked how, when and at what cost it could mount a sample return mission. "We want to be in a position to give a good answer," he said. The study group, to be chaired by Dan McCleese of the Jet Propulsion Laboratory in Pasadena, California, hopes to have a quick analysis ready for next week's meeting of the agency's advisory group on Solar System exploration.

The "summit" announced by President Bill Clinton, to be chaired by Vice-President $\mathrm{Al}$ Gore, is in fact a belated response to a call earlier this summer by Senator Barbara Mikulski (Democrat, Maryland) for a meeting of White House and congressional leaders to discuss issues related to long-term

\section{India loses vaccine manufacturing project}

New Delhi. A US $\$ 80$ million Indo-French vaccine project launched in 1989 is being wound up before a single drop of vaccine has been produced. India's Department of Biotechnology says that this is the direct result of the French company reneging on a promised technology transfer deal.

In partnership with India, Institut Marieux (IM) of France was to set up on the outskirts of Delhi one of the world's largest plants for manufacturing measles, rabies and injectable polio vaccines. The agreement included a FF69 million (US\$13.8-million) credit from the French government, given direct to IM as payment for the transfer of technology and equipment to India.
But the project ran into trouble when. the ownership of IM - renamed Pasteur Marieux Serum Vaccines (PMSV) shifted to private hands (see Nature 360,$3 ; 1992$ ). The new company considered that the transfer of the proprietary 'vero' cell technology - which allows mass production of vaccine in fermenters rather than using animals did not make business sense.

"The company was just waiting for a chance to pull out," says a spokesman for the Department of Biotechnology. The opportunity came when the Indian health ministry decided to use oral vaccine instead of the injectable form intended in the original agreement. PMSV's representative in India declines to comment.

K. S. Jayaraman further examination

policy-makers.

of Martian meteorites - would probably involve other agencies besides NASA, including the National Science Foundation (NSF) and perhaps the Department of Defense, which has pioneered advanced miniaturized spacecraft technology.

Neal Lane, the director of NSF, was careful to point out last week that the meteorite containing the purported fossil was collected by NSF researchers in Antarctica, and that the advanced microscopes used to study the samples resulted from US investment in scientific instrumentation. Richard Zare of Stanford University in California, a member of the team that announced the find last week and the new chairman of the National Science Board, which governs the NSF, took the opportunity to argue for more support for Antarctic research, which, he said, is "woefully underfunded".

International Mars missions may also get a boost from last week's announcement. Although the European Space Agency (ESA) by-passed a proposal called InterMarsnet in favour of an astrophysics mission this year, space scientists on both sides of the Atlantic are still hopeful that some remnant will resurface in a future joint mission. An international Mars exploration working group, set up in 1994 to coordinate the plans of NASA, ESA, Russia and other European national space agencies, has its next meeting in December.

By that time, the US space summit will have taken place, three Mars missions (including one from Russia) will have been launched, and the world will have had several months to see whether the claim of past life on Mars holds up to scientific scrutiny.

Tony Reichhardt 